\title{
Guerra, Formação do Estado e Identidade Nacional nas Franjas do Mundo Atlântico
}

\author{
Eoin O'Neill
}

\section{INTRODUÇÃO: ESTADOS E HISTÓRIA}

T ão é de hoje que o Estado tem sido objeto central das ciências sociais. História, ciência política, sociologia, todas essas disciplinas têm o Estado como eixo na medida em que as unidades de análise adotadas são os Estados existentes - ou o contexto político no qual a análise se desenvolve é baseado neles. Para além disso, em muitos estudos o Estado atual é projetado no passado, sendo a "História" encaixada nas exigências geográficas e culturais das histórias nacionais ou colocada dentro das fronteiras de um Estado moderno. As complexidades, reviravoltas e contradições dos processos sociais, que constituem os processos nacionais ao longo de séculos, são amalgamadas e encobertas sob rubricas como história da Inglaterra, da Irlanda ou da França.

A "História" da Inglaterra - Grã-Bretanha1 após 1603 - é expressiva nesse sentido. Presume-se que o Estado inglês teria existido mais ou menos inalterado desde a invasão de Guilherme da Normandia, apesar das várias mudanças significativas de regimes (a Guerra das Rosas e várias outras lutas medievais, a Guerra Civil "Inglesa”, as guerras jacobitas, a emergência da democracia etc.). A Inglaterra torna-se um conceito sociopolítico assumido como dado em si. A Inglaterra de então seria a mesma Inglaterra de hoje ${ }^{2}$, do mesmo modo que os ingleses de hoje seriam aqueles que sempre foram ingleses (excluindo-se ape-

DADOS - Revista de Ciências Sociais, Rio de Janeiro, Vol. 51, n-1, 2008, pp. 239 a 260. 
nas os imigrantes não-brancos das antigas colônias). O fato de a coroa inglesa ter governado por longos períodos zonas da França e da Inglaterra que não pertencem mais à Grã-Bretanha - e de várias pessoas dessas regiões se considerarem inglesas - é consideração irrelevante nessa história desenhada a partir dos Estados modernos. Isso é ainda mais irônico quando se lembra que a Inglaterra atualmente não é nem um Estado moderno nem uma região. Oficialmente existe apenas enquanto entidade independente no futebol, no rúgbi e em alguns outros esportes. Além disso, antes mesmo de 1603, o Estado inglês, como exposto com grande propriedade por Ellis (2002), não era uma nação nem um Estado nacional. Tratava-se antes de um Estado multinacional, multicultural e multilingüístico, que englobava os povos ingleses, galeses, irlandeses e franceses:

\footnotetext{
Na verdade, tanto o Estado inglês como seu sucessor no século XVII, a monarquia britânica múltipla, eram Estados multinacionais. A monarquia Tudor, por exemplo, reinava sobre quatro povos diversos (inglês, irlandês, francês e galês). O recurso a definições modernas de nações e territórios nacionais distorce profundamente o contexto do governo monárquico Tudor. O Estado inglês é encarado não como um Estado multinacional e como uma monarquia múltipla mas antes como um Estado-nação (de fato um Estado-nação muito precoce!). Todavia, não tem qualquer cabimento descrevê-lo desse modo quando se analisa o período após a conquista anglo-saxã da Inglaterra pelos duques da Normandia em 1066 - Gales foi incorporado através de conquista nos séculos XII e XIII; metade da Irlanda no século XIII e o resto no XVI (ibidem:101, tradução do autor).
}

Os escoceses foram agregados ao conjunto após 1603, quando James VI da Escócia assumiu o trono inglês, transformando o Estado numa monarquia múltipla consistente de três reinos: Inglaterra, Escócia e Irlanda. Pode-se ainda acrescentar que sua ascensão ao trono ocorreu no bojo de um longo processo de redesenho da identidade nacional em várias partes desse reino múltiplo. Ser inglês crescentemente passou a estar restrito àqueles (do ponto de vista religioso, protestantes) nascidos na Inglaterra, com a conseqüente exclusão de comunidades há tempos encaradas como inglesas na Irlanda e na França. A correspondência, na Irlanda, foi o forjar de uma nova identidade irlandesa, oposta às identidades anteriores que diferenciavam os ingleses-irlandeses (IrishEnglish) - também anglo-irlandeses (Anglo-Irish) ou antigos ingleses (Old English) - dos irlandeses gaélicos (Gaelic Irish). Na seqüência das 
derrotas da, essencialmente católica e gaélica, Confederação de Hugh O'Neill na Guerra dos Nove Anos (1594-1603), da Confederação Católica na década de 1640 e dos jacobitas nos anos 1690, bem como das transformações sociais que daí resultaram - em especial a erradicação progressiva do direito dos católicos à posse de terras -, o antagonismo entre gaélicos (Gaelic) católicos e antigos ingleses (Old English) católicos cessou e foi substituído por uma nova categoria, a de católicos irlandeses (Catholic Irish).

Um exemplo significativo desse processo é o cunhar do termo Éireannaigh no primeiro quartel do século XVII. Foi a primeira palavra para irlandês (Irish) cunhada na língua gaélica. Embora, por um lado, isso apontasse para a criação de uma natio irlandesa (católica), também evidenciava uma ruptura no mundo gaélico. Este caracterizava-se por uma entidade política dividida, com vários elos de poder competindo entre si e uma cultura unificadora e homogeneizadora. Dividia-se tradicionalmente entre os Gaedhil e os Gaill - os membros do povo gaélico e os estrangeiros, respectivamente. A área de cultura gaélica, Gaeltacht, incluía tanto a Irlanda quanto a Escócia. Até o acesso de Jaime ao trono inglês, os efeitos dessas divisões políticas no mundo gaélico viam-se mitigados pela incapacidade tanto de Londres quanto de Edimburgo de impor seu domínio sobre as periferias gaélicas. A unificação dos tronos inglês e escocês sob Jaime representou o início da ruptura do mundo gaélico, sobretudo em função do colapso do poder militar e da autonomia gaélicos que se sucedeu à derrota de Hugh O'Neill, com sua partida para o continente em 1607, bem como a ataques ao poder gaélico nas Terras Altas da Escócia.

Processos de complexidade semelhante ocorreram praticamente em qualquer um dos Estados europeus atuais, incluindo os que constituíram o próprio núcleo do sistema europeu de Estados. As formas dos Estados sofreram modificações consideráveis. Estados-nação, cidades-Estado, ligas comerciais e uma variedade de reinos sobrepuseram-se, misturaram-se e complementaram-se. Ao final, o Estado-nação (ou, como melhor expresso por Tilly, o Estado nacional) triunfou. Mais ainda, em função dos impérios coloniais dos Estados nacionais europeus, tal forma de Estado tornou-se dominante ao redor do mundo (ver Tilly, 1990). Não obstante, o conceito mesmo de nação ou de Estado nacional abrange uma enorme variedade de formas estatais. Inclui Estados nacionais tradicionais, tais como a Irlanda ou a Finlândia, Estados múltiplos/compostos, como o Reino Unido ou a Espanha, 
cidades-Estado modernas, a exemplo de Cingapura, Estados continentais, como os Estados Unidos e o Brasil, e Estados enormes, multiétnicos, multirreligiosos e multiculturais, tais como China, Índia ou Rússia, este último correspondendo a uma grande diversidade de esferas de poder e níveis de autonomia.

Isso estabelece uma dificuldade para os historiadores e outros cientistas sociais: decidir qual é a macrounidade de análise apropriada. Como mencionado, a maioria dos trabalhos de ciências sociais são estruturados a partir dos Estados nacionais contemporâneos. Apesar das vantagens, essa abordagem não deixa de apresentar problemas, sobretudo quando se faz necessário incorporar observações historiográficas. Por exemplo, um estudo da Flórida nos séculos XVII e XVIII seria muito provavelmente estabelecido como parte da história norte-americana do início do período moderno (ou colonial), e não como história espanhola, apesar de a Flórida ser nessa época parte da Espanha e de suas elites se considerarem espanholas. A pesquisa histórica pode levar a questionamentos de vários aspectos das ciências sociais que tomam os Estados nacionais como base. Considerando ainda o exemplo da Flórida, quando é que a história (norte-) americana começa? Com a chegada dos exploradores espanhóis e franceses? Com o estabelecimento das colônias inglesas? Com a declaração de independência?

Nada do que foi comentado vai no sentido de questionar a importância do Estado ou sua centralidade nas ciências sociais. Muito pelo contrário, encaro Estado como um conceito fundamental que, por isso mesmo, não deve ser percebido como algo transcendente ou "eterno" e imutável. Os Estados são instituições sociais; portanto, instituições socialmente construídas. Embora tenham um grau significativo de permanência e estabilidade, nem por isso deixam de ser dinâmicos. Evolvem e se transformam. É o caso, por exemplo, do Estado britânico moderno após perder seu império e seu papel de liderança em âmbito mundial - o Produto Interno Bruto - PIB per capita foi superado pelo da Irlanda, sua pretérita colônia -, não sendo, é claro, o mesmo Estado inglês de Henrique VIII, que incluía Inglaterra e País de Gales (embora não a Escócia), bem como territórios na Irlanda, além de Calais. Tampouco é o mesmo Estado britânico da década de 1940, que ainda era um potentado no cenário mundial e um império. Outro exemplo de mudanças significativas que ocorrem no âmbito dos Estados - até mesmo em períodos curtos de tempo - pode ser encontrado numa comparação entre os Estados europeus ocidentais de bem-estar social nas décadas 
de 1950 e 1960 e seus sucessores na última década do século XX e início do XXI, quando o sistema de bem-estar social sofrera profundas modificações.

Os Estados não são instituições reificadas, como se congeladas no tempo. Ao contrário, como já pontuei, são instituições construídas, adaptadas, transformadas, reformadas e destruídas por meio de processos sociais. Uma míriade de fatores está envolvida nos processos sociais de formação do Estado, tanto internos quanto externos. Podem-se incluir fatores financeiros e econômicos, religiosos, desastres naturais, mudanças culturais, ideologias e até guerras e invasões. Um aspecto também com freqüência fundamental são as relações entre as elites e outros grupos sociais relevantes. Acredito que o papel e a estrutura do Estado contemporâneo não podem ser adequadamente compreendidos sem que se levem em conta os processos históricos ocorridos em cada Estado. Desse modo, a natureza específica do Estado na Irlanda onde é extremamente centralizado e poderoso, embora esse "poder" em larga medida não seja aparente - não pode ser entendida senão em ligação com a relação colonial do país com a Grã-Bretanha, em especial o caráter centralizado da administração britânica na Irlanda, o papel do catolicismo e os efeitos das guerras de Independência e Civil.

Para além disso, quando se observa o processo de formação do Estado num país (ou nação, ou região) específico, é preciso identificar seus períodos-chave. Em relação aos Estados europeus, vários historiadores consideram o fim do século XVI e a primeira metade do XVII como um desses períodos básicos - grosso modo, a Era das Guerras Religiosas. Outras épocas-chave foram a Era das Revoluções e a Era Napoleônica (1789-1815), bem como as décadas de 1930 e 1940. Quando nos voltamos para países específicos, sobretudo os da periferia, essa periodização pode ser um pouco distinta. No caso da Irlanda, como defendi em minha tese de doutorado (O'Neill, 2005), o evento básico detonador da mudança foi a Guerra dos Nove Anos (Nine Years War) (1594-1603), que acabou por corresponder à conclusão da conquista inglesa do país e à subjugação dos lordes gaélicos, bem como ao fim da autonomia de seus senhorios. Essa dura vitória inglesa é de importância fundamental para a Irlanda, porque representou o fim da possibilidade de um modelo alternativo de desenvolvimento. Mais ainda, foi também crucial para o desenvolvimento posterior do Estado inglês - muito embora esse aspecto pareça ser apenas reconhecido por historiadores irlandeses, ou por historiadores que produzem de uma perspectiva irlande- 
sa, e ignorado pela maioria dos historiadores ingleses ${ }^{3}-$, no sentido em que uma derrota inglesa teria ameaçado o acesso dos Stuarts ao trono inglês e provavelmente imposto restrições a seu absolutismo. A vitória também assegurou uma orientação em direção ao Ocidente - Américas e além. É bem possível que, se os confederados sob a liderança de Hugh O'Neill não houvessem sido derrotados, o Império Britânico teria sido diferente e de menor porte. Por fim, a vitória inglesa foi obtida a um altíssimo custo financeiro, que recaiu sobre os Stuarts e teve grande importância na corrosão das relações entre as elites inglesas nas décadas de 1630 e 1640. Introduziu ainda um elemento de desestabilização (a Irlanda) na entidade política britânica - uma questão que, apesar dos avanços significativos nos últimos anos, ainda está longe de inteiramente resolvida.

O objetivo deste artigo é analisar e refletir sobre a formação de Estados na Europa Ocidental, indo além do foco teórico apenas em uma ou duas variáveis-chave (tais como guerra ou comércio) e enfatizando processos dinâmicos que envolvem a interação de grande quantidade de fatores variáveis. Para além disso, em vez de atentar para um país específico ou procurar comparar dois países com situações semelhantes, como a Inglaterra e a Holanda, pretendo tomar como objeto a Inglaterra e a Irlanda, dois Estados inter-relacionados que, sob muitos aspectos, tiveram trajetórias que se contradisseram.

A Inglaterra representava o núcleo, a metrópole, o centro de um Estado multinacional e, posteriormente, de um império que durante certo período foi a maior potência mundial. A Irlanda, por outro lado, constituiu a primeira "colônia" da Inglaterra; estava na periferia geográfica, econômica e política. Isso não impede que a formação do Estado nos dois países tenha estado intrinsecamente ligada. O processo de formação do Estado na Irlanda, apesar de ter sido imposto sob muitos aspectos por meio de violência, coerção e repressão, influenciou o processo correlato inglês de várias maneiras e teve, por extensão, impacto na história mundial. Apesar de enfatizar um processo dinâmico de formação de Estado, não obstante acredito que alguns aspectos foram mais relevantes do que outros. Houve momentos básicos durante os quais foram tomadas decisões-chave que, em certa medida, acabaram por determinar os caminhos futuros. O longo século XVII - da Grande Armada espanhola em 1588 até as guerras jacobitas de 1689-1691 - foi um desses períodos centrais, como esboçado a seguir. 


\section{A FORMAÇÃO DO ESTADO NA COLÔNIA E NA METRÓPOLE: INGLATERRA E IRLANDA NO SÉCULO XVII}

A intervenção inglesa na Irlanda começou no século XII. Como ironicamente voltaria a ocorrer no período elizabetano, as políticas iniciais da coroa inglesa resultaram da pressão de interesses privados. No início desatento ao país (do qual havia convenientemente ganho senhorio do Papa), Henrique II na verdade só com ele se envolveu após o sucesso manifesto de alguns de seus lordes na Irlanda. A ameaça de que alguns desses lordes poderiam de fato estabelecer um reino independente levou Henrique a ir pessoalmente à Irlanda. Apesar dos anglo-normandos terem rapidamente conquistado parcela significativa do país, foram incapazes de assumir o controle de tudo. Mais ainda, apesar do afluxo de um número considerável de colonos ao longo de várias gerações, a cultura gaélica pregressa nunca fora inteiramente substituída, nem mesmo em áreas controladas pelos lordes anglo-normandos. Com freqüência ocorreu o oposto: os novos lordes adotaram hábitos e aspectos da cultura gaélica, tornando-se - como na expressão famosa mas talvez não inteiramente precisa - "mais irlandeses do que os próprios irlandeses".

Após cerca de um século da invasão normanda, os colonos encontravam-se na defensiva. No oeste e no norte da Irlanda, os lordes gaélicos haviam conseguido reverter o controle anglo-normando, com destaque para seu declínio e colapso no condado do Ulster (Earldom of Ulster). Essa reconquista gaélica em parte foi fruto de oportunidade: a atenção da coroa inglesa estava voltada para a França, ao passo que os próprios lordes anglo-normandos se digladiavam profundamente entre si. Outro fator significativo foi a intervenção externa. A partir do século XIII, os lordes gaélicos começaram a importar mercenários das Ilhas e das Terras Altas da Escócia (os Gallóglaigh ou Gallowglasses) e, no início do século XIV, Edward Bruce, irmão de Robert, desembarcou na Irlanda. Embora no final Bruce tenha sido derrotado, sua intervenção enfraqueceu fortemente a Inglaterra na colônia.

No início da Era Tudor, a Irlanda estava mais ou menos dividida em três zonas cujas fronteiras eram flexíveis. A primeira zona correspondia ao Pale - também conhecido como Pale inglês -, a região da costa leste e terras do interior, revolvendo em torno dos condados de Dublin, Kildare e Meath, culturalmente inglesa e aceitando em boa medida o domínio do governo em Dublin. As cidades e vilas forais em outras 
áreas do país, sobretudo no sul, também faziam parte dessa zona (aliás, com mais privilégios e maior autonomia). A segunda compreendia os domínios dos potentados antigos ingleses (Old English) ou ingleses-irlandeses (Irish-English), os domínios dos Kildare, dos Desmond e dos Ormond, mas também vários outros domínios menores. Detendo maior autonomia do que o Pale, mantinham uma atitude razoavelmente amigável em relação ao governo, desde que sua autonomia e privilégios fossem respeitados. A última zona era a dos domínios gaélicos ou gaelicizados dos O'Neills e dos O'Donnells no Ulster, dos O'Briens e dos MacCarthys em Munster, dos MacWilliam Burkes em Connaught e dos O'Byrnes em Wicklow. Apesar de possuírem grande autonomia, esses domínios não necessariamente se opunham ao governo (vários lordes de menos importância eram-lhe bastante favoráveis, encarando um governo em Dublin ou em Londres como algo preferível a um suserano mais próximo), desde que a autonomia e os privilégios - posteriormente, também a religião - fossem respeitados. Todavia, uma sucessão de monarcas da dinastia Tudor se mostrou incapaz de fazê-lo, dando origem a uma série de convulsões no país. É também importante reiterar que essas três áreas não eram mutuamente excludentes, havendo considerável interação entre elas ${ }^{4}$.

De forma análoga, a população da Irlanda dividia-se entre os irlandeses gaélicos (Gaelic Irish) ${ }^{5}$ e os antigos ingleses (Old English), estes últimos constituindo a maioria da população das cidades e do Pale. Havia grande mistura entre os dois grupos, o que está amplamente documentado para as famílias nobres e que se pode presumir que também ocorreu nas classes mais "invisíveis". Na verdade, uma das principais críticas dirigidas aos antigos ingleses (Old English) pelos ingleses e pelos novos colonos - chamados de novos ingleses (New English) - é que eles haviam degenerado em irlandeses. O mais eloqüente dos novos colonos, o poeta Spenser, identifica especificamente o recurso a amas-deleite gaélicas como causa dessa degeneração (1997:71).

Para os Tudor, a situação na Irlanda, especialmente em função da permanência de "súditos excessivamente poderosos" (tanto falantes de gaélico quanto de inglês), era inaceitável seja ideológica, seja politicamente. A necessidade de a coroa inglesa se apoiar em alguns desses "súditos" para governar o país agravava essa situação. Para além disso, o fato de a Irlanda ser usada como cunha para várias invasões da Inglaterra por pretendentes iorquistas (Yorkists) ao trono e por inimigos do continente para fomentar agitação fez com que vergar a autono- 
mia dos domínios irlandeses se tornasse uma necessidade estratégica urgente. Tal empreendimento acabou, todavia, por se mostrar profundamente complexo e custoso, desestabilizando o regime dos Tudor; e sua conclusão minou o regime dos Stuarts. A culpa recai nos monarcas Tudor, em especial em Elizabeth ${ }^{6}$, cujo regime foi provavelmente o mais sangrento da história da Irlanda.

A situação política na Irlanda complicou-se ainda mais com a Reforma. Muito embora a ruptura de Henrique VIII com Roma tenha sido inicialmente aceita sem maiores problemas na Irlanda, o oposto ocorreu com reformas mais radicais que tentou introduzir. Em contraste com isso, e apesar de uma recepção modesta em seu início, a Contra-Reforma rapidamente ganhou terreno, permanecendo católicos tanto os irlandeses gaélicos (Gaelic Irish) quanto os antigos ingleses (Old English). Isso contribuiu para a mudança de atitude da Inglaterra em relação aos antigos ingleses (Old English), cuja lealdade para com o Estado passou a estar sob suspeição. A comunidade dos antigos ingleses (Old English), não obstante, apesar de rejeitar a igreja oficial, permaneceu convicta de sua Englishness e agarrada a seu conceito de lealdade. Embora tenham permanecido leais ao monarca inglês (após 1534, também rei - ou rainha da Irlanda), recusaram-se a abrir mão de seus privilégios políticos e econômicos, resistindo tanto quanto possível às tendências absolutistas do regime de Londres. Foi, aliás, tal senso de lealdade que fez com que a nobreza dos antigos ingleses (Old English) não sustentasse a Confederação Católica de Hugh O'Neill na Guerra dos Nove Anos, embora não tenha impedido que participasse da Confederação de Kilkenny na década de 1640, a qual era, ao menos explicitamente, realista.

Muito embora tanto os antigos ingleses (Old English) quanto os novos ingleses (New English) defendessem a reforma da Irlanda gaélica, suas noções de reforma eram significativamente diferentes. De modo geral, os antigos ingleses (Old English) tendiam a ser favoráveis a uma reforma política baseada em princípios humanistas básicos. Os novos ingleses (New English), todavia, em função da influência de ideais puritanos e calvinistas, tendiam, especialmente por volta do fim do século XVI, a encarar a espada como meio de reforma. Propunham uma política de quase genocídio, a qual, à medida que a situação no país se tornou crescentemente mais complexa, também se tornou crescentemente mais radical. Na década de 1590, vários, especialmente novos, colonos defendiam extirpar e exterminar a cultura gaélica, os lordes e a elite gaélica. Diversas rebeliões e conflitos, em particular as Guerras dos Des- 
mond e a Guerra dos Nove Anos, forneceram o pretexto ideal para a implementação dessas políticas ${ }^{7}$.

Um fator complicador a mais foi o caráter "privatizado" do Estado. O governo inglês era essencialmente corrupto. Compravam-se e vendiam-se postos; uma vez que um indivíduo tivesse ocupado um posto, tornava-se, com freqüência, muito difícil removê-lo. Na medida em que o preço dos postos era elevado e os salários eram baixos, a maneira mais óbvia de recuperar o "investimento" era por meio de corrupção. Isso também encorajava os funcionários do Estado a perseguir seus interesses próprios, até mesmo em detrimento da política de Estado ${ }^{8}$. Muito embora em Londres e na Inglaterra fosse possível controlar os oficiais do governo até certo ponto, na Irlanda o oposto era verdadeiro, o que permitiu a funcionários do governo e do Exército construir pequenos impérios, caso de Richard Bingham em Connaught e de George Carew em Munster. O impacto das atividades dos funcionários voltados para seu próprio enriquecimento era considerável, abalando a confiança dos lordes gaélicos no Estado. Um exemplo é a corrupção de William Fitzwilliam, lorde encarregado-geral (lord deputy) no início da década de 1590, uma das causas do início das hostilidades entre o Estado e os confederados de Hugh O'Neill'.

A Guerra dos Nove Anos foi marco de virada essencial na história moderna irlandesa - e um dos mais importantes na história britânica. O que começou como um conflito regional envolvendo uma coalizão de lordes gaélicos revoltosos transformou-se, pela virtú do líder gaélico Hugh O'Neill e pela incompetência de Elizabeth e seu governo, numa guerra de âmbito nacional, que se tornou parte integrante da guerra continental maior entre Espanha e seus aliados, de um lado, e Holanda, Inglaterra e França, de outro. O sucesso da confederação gaélica ameaçou o domínio inglês na Irlanda, bem como a própria estrutura do Estado inglês. Uma vitória gaélica (ou uma "não-derrota") haveria provavelmente resultado num Estado muito menos centralizado, no qual uma variedade de domínios quase autônomos - e fontes potenciais de oposição ao Estado - continuaria a existir. Isso teria posto dificuldades à extensão da legislação inglesa e à ligação financeira do conjunto do país. Como resultado da contribuição espanhola ao esforço gaélico de guerra, uma vitória confederada quase certamente introduziria uma presença não-inglesa significativa na unidade política, que representaria outra fonte potencial de hostilidade/conflito. É provável ainda que 
isso pusesse empecilhos ao acesso de Jaime VI da Escócia ao trono inglês, uma vez que o monarca espanhol também era pretendente.

Um último - dentro de uma perspectiva internacional, talvez o mais significativo - efeito potencial estaria na trajetória futura da Inglaterra/(Grã-)Bretanha como poder imperial. Do ponto de vista geopolítico, a Irlanda tanto serviu de porta de entrada para atacar a Inglaterra quanto se transformou em porta de saída desta em direção ao Ocidente. Durante o período medieval e a maior parte do Tudor, os monarcas ingleses estavam voltados para o leste, para a França e para o continente. O comércio inglês também era orientado para a Europa. Durante as últimas décadas do século XVI, após a perda do último baluarte inglês na França e na mira das oportunidades de pirataria e saque em possessões espanholas, a perspectiva estratégica do Estado inglês começou a girar no sentido do Ocidente. Contudo, tal perspectiva ainda era dominada pela guerra com a Espanha, os principais enfrentamentos ocorrendo na Holanda, na Bretanha e na Irlanda. Apenas após a Irlanda estar completamente subjugada se abriu o caminho para a Inglaterra se tornar um poder global. Além disso, como Canny (1988) e outros apontaram, os experimentos coloniais ingleses (e britânicos) no Novo Mundo estiveram intimamente conectados com os experimentos na Irlanda. As plantations na Irlanda, em especial no Ulster e em Munster, absorveram bem mais gente e recursos do que as nas Américas ao longo do século XVII. Foram também francamente melhor sucedidas e, em certa medida, menos arriscadas. Para além disso, várias pessoas em comum estiveram envolvidas nos esquemas de colonização na Irlanda e no Novo Mundo, sendo instrumentais nas Américas a experiência e as técnicas adquiridas na Irlanda. Havia ainda laços ideológicos: parte dos envolvidos nos empreendimentos coloniais na Irlanda e nas Américas oferecia justificativas ideológicas idênticas para suas ações.

No tocante a padrões de desenvolvimento do Estado na Irlanda, a vitória do governo na Guerra dos Nove Anos representou o fim da possibilidade de trajetórias alternativas, tais como a emergência de um Estado "irlandês". A Irlanda passou então a estar inteiramente submetida ao Estado inglês, tornando-se um Estado colonial centralizado, e não mais um reino-irmão em que o domínio da lei se baseava na coerção (Edwards, 2004), os antigos direitos e privilégios da comunidade católica leal se haviam esboroado, a maioria parlamentar se constituía a partir dos colonos protestantes e a posse da terra revertia, cada vez mais, por meio de processos extralegais e econômicos, para os novos 
colonos. Para além disso, apesar da preocupação expressa por vários autores da época a respeito dos excessos da lei gaélica e da necessidade de civilizar os irlandeses gaélicos (Gaelic Irish) a fim de "melhorá-los", no momento em que a Irlanda gaélica deixou de ser percebida como uma ameaça, tais idéias se esfumaçaram. Na verdade, vários lordes gaélicos importantes, tais como Cormac MacBaron, irmão de Hugh O'Neill, e Niall Garbh O'Donnell, sofreram prisão perpétua sem acusação formada. Outros foram executados com base em acusações forjadas. Dessa forma, o colonizado, uma vez conquistado, foi sujeito a uma nova forma de guerra, na qual as principais armas assumiam roupagem legal. A lei inglesa foi usada para atacar e remover mecanismos legais do sistema anterior julgados inconvenientes, bem como para enfraquecer o acesso à terra, solapar e enfraquecer o poder de lordes e debilitar a oposição. Na sua interessante análise desse "imperialismo legal", Pawlisch (1985) mostrou como, com base na experiência obtida na Irlanda, os ingleses posteriormente implementaram empreendimentos e procedimentos análogos em suas colônias e conquistas.

Naturalmente, isso gerou reações. Os irlandeses gaélicos (Gaelic Irish) e os antigos ingleses (Old English) não foram meros receptores passivos das mudanças cruciais que ocorriam, mas sim envolveram-se em reações de múltiplas ordens: política, militar, religiosa e ideológica. Uma quantidade significativa de irlandeses gaélicos (Gaelic Irish) e antigos ingleses (Old English) foi para o continente, em especial para domínios espanhóis. Alguns se juntaram aos regimentos irlandeses do Exército da Flandres ou se tornaram exilados políticos. Outros foram educar-se ou tornar-se padres nas várias universidades irlandesas estabelecidas no continente. Isso contribuiu para uma espécie de Renascença gaélica, na qual os estudiosos - normalmente pertencentes a ordens religiosas tentavam, de um lado, preservar sua cultura e, de outro, contribuíam para a formação de uma identidade irlandesa. A palavra Éireannaigh, termo gaélico para irlandês, substantivo que antes jamais existira, foi cunhada nessa época. A nova identidade baseava-se mais no catolicismo do que em etnicidade. A distinção anterior entre gaélicos (Gaelic) e antigos ingleses (Old English) foi erodida e eventualmente acabou por ser substituída por uma nova categoria abrangente: irlandeses católi$\cos$ (Catholic Irish). Essa identidade, todavia, só assumiria caráter pleno no fim do século XVII, e o conflito entre os dois grupos permaneceria, em detrimento de ambos. Tal identidade constituiu-se, além disso, em oposição ao Estado. Apesar de tentativas de acomodação ao Estado protestante, os católicos leais acabaram por não ser bem-sucedidos. 
Sua lealdade era rejeitada pela entidade política inglesa, crescentemente anticatólica, que tanto suspeitava dos católicos quanto se recusava a aceitar os antigos ingleses (Old English) como ingleses (cf. Caball, 1998).

As convulsões por que o Estado inglês passou durante o regime de Carlos I complicaram ainda mais a situação. O absolutismo político e religioso do rei Stuart não dava espaço para compromisso, muito embora este fosse desesperadamente necessário em função da situação financeira crítica da coroa inglesa, cuja origem em boa parte pode ser remontada à Guerra dos Nove Anos. Isso levou a conflitos na Inglaterra entre a coroa e o Parlamento, e entre a coroa e os covenanters religiosos escoceses. Tentativas de mobilizar os católicos irlandeses no apoio a Carlos I nessa guerra com os covenanters fracassaram, e o rei foi forçado a um acordo de paz humilhante. Foi então que a guerra estourou na Irlanda, na seqüência do levante da nobreza católica no Ulster, em 1641, o qual rapidamente se espalhou por toda a ilha. As razões dessa rebelião foram múltiplas, mas, em suma, parecem advir do colapso da confiança das elites católicas na coroa, do medo generalizado entre os católicos do Parlamento virulentamente anticatólico em Westminster e do fato de boa parte da pequena nobreza católica da Irlanda estar fortemente endividada. O Levante de 1641 na Irlanda foi o detonador próximo da Guerra Civil Inglesa, hoje chamada de Guerra dos Três Reinos.

A Inglaterra, a Escócia e a Irlanda foram esfaceladas pela guerra durante a década de 1640. A Irlanda, todavia, foi o país que mais sofreu. Apesar da Confederação de Kilkenny, que juntou irlandeses gaélicos (Gaelic Irish) e antigos ingleses (Old English), suspeições mútuas e divisões solaparam fatalmente essa unidade. Enfraquecidos por lutas intrincadas de facções e pela morte de seu melhor comandante militar, Eoghan Ruadh O'Neill, sobrinho de Hugh O'Neill, os confederados não eram páreo para Cromwell quando ele desembarcou na Irlanda em 1649. Dois anos mais tarde, a Irlanda havia sido inteiramente submetida, e Cromwell ganho o lugar mais elevado no pedestal do ódio irlandês. À vitória seguiram-se novos empreendimentos de colonização. Grande parte dos donos de terras católicos perderam suas posses, alguns sendo expulsos para a província irlandesa mais pobre, Connaught, enquanto muitos soldados, mulheres e crianças eram enviados como escravos para as novas colônias inglesas nas Índias Ocidentais. 
Eoin O'Neill

Apesar das esperanças dos irlandeses católicos leais à coroa, a colonização e a distribuição de terras de Cromwell foram mantidas após a restauração da monarquia em 1660 . O acesso ao trono do católico Jaime II parecia poder ameaçar o sistema - certamente vários católicos e protestantes acreditaram nessa possibilidade. Embora algumas leis anticatólicas tenham sido barradas na Irlanda e houvesse de fato planos de rever a questão da terra, a deposição de Jaime II deveu-se essencialmente, não obstante a eloqüente propaganda contrária, a preconceitos anticatólicos. A conseqüência foi uma piora dramática na situação dos católicos na Irlanda. Após a rendição das forças jacobitas na Irlanda em 1691, com a subseqüente ida para o exílio de grande quantidade de soldados, foram introduzidas na Irlanda as infames Leis Penais (Penal Laws) anticatólicas. Isso teve como resultado praticamente eliminar a nobreza católica na Irlanda e, de modo mais geral, a posse de terras por católicos.

O período de 1590-1691 foi chave em termos da formação dos Estados modernos na Irlanda e na Grã-Bretanha. Enquanto em 1590 a Escócia constituía um reino independente e a Irlanda mantinha uma relação ambígua com a Inglaterra, possuindo razoável autonomia, em 1691 os três países estavam unidos sob a mesma coroa, a Irlanda havia sido inteiramente conquistada (por três vezes), os domínios nobres autônomos eliminados e a cultura política gaélica essencialmente erradicada (fado que recairia sobre a Escócia daí a sessenta anos). O reino da Irlanda fora transformado em colônia. Além disso, suas estruturas social e econômica também haviam sido modificadas. Não obstante a maioria da população do país ser católica, basicamente toda a terra estava sob a posse de protestantes, ao que se juntava a substituição da divisão anterior entre irlandeses gaélicos (Gaelic Irish) e antigos ingleses (Old English) por uma nova identidade irlandesa baseada no catolicismo. Analogamente, uma nova identidade inglesa emergira, baseada no protestantismo e que rejeitava de modo explícito a demanda dos antigos ingleses (Old English) de serem considerados ingleses, já que sua teimosia em permanecer católicos os teria feito degenerar em irlandeses.

Nos dois séculos seguintes, a Grã-Bretanha tornar-se-ia uma potência mundial, senhora de um império que alcançava os quatro cantos do globo. A rota para se tornar a potência dominante no mundo foi aberta com a vitória inglesa na Guerra dos Nove Anos. Todavia, no mesmo passo, a subjugação, a "colonização" da Irlanda criou um problema irlandês para a Grã-Bretanha. Não obstante os avanços ocorridos nessa 
última década, esta é uma questão ainda longe de inteiramente resolvida. A incorporação da Irlanda também agravou tensões inerentes ao Estado britânico, criando uma espécie de problema britânico: como forjar uma unidade entre três Estados (e quatro nacionalidades, contando os galeses) que foram postos juntos à força; o que a longo prazo se mostrou impraticável por causa dos irlandeses católicos. Isso não significa que os católicos irlandeses se opusessem sistematicamente à idéia de uma Grã-Bretanha ou de um Império Britânico. Bem pelo contrário, vários católicos irlandeses participaram e se beneficiaram dessas entidades. Todavia, os eixos ideológicos centrais utilizados para unificar, "criar" e "inventar" a Grã-Bretanha sistematicamente excluíam os católicos irlandeses (bem como criavam várias contradições para os ingleses católicos e os escoceses). Esses eixos giravam em torno dos temas interligados coroa, religião (protestantismo, tanto anglicano quanto calvinista, e anticatolicismo), o império britânico e sua missão colonial civilizadora, um sentimento profundamente calvinista de densidade e crença de que os ingleses - em certa medida também os escoceses e os galeses - eram o povo escolhido por Deus (com a correspondente discriminação/racismo contra os povos que não haviam sido tão afortunados), crença no regime da assim chamada "Revolução Gloriosa", bem como um sentimento de equivalência entre britânico e inglês. Esses princípios - que tiveram um impacto muito direto na formação do Estado na Inglaterra e na Irlanda - inevitavelmente solaparam a possibilidade de efetivar a incorporação da Irlanda ao seio da Grã-Bretanha ${ }^{10}$.

É interessante comparar as dificuldades sistemáticas da incorporação da Irlanda à Grã-Bretanha com sua quase ausência no caso da Escócia. Como a Irlanda, a Escócia tinha franjas gaélicas que eram analogamente desprezadas pelos habitantes "civilizados" de Edimburgo. Sua elite política também era constituída por descendentes de colonos e falantes de inglês. Diferentemente da Irlanda, a Escócia era um reino independente. Todavia, essa independência foi oferecida com relativa facilidade. Embora tivesse havido várias rebeliões jacobitas no século XVIII, estas (incluindo-se a mais bem-sucedida, a "Quarenta e Cinco") não ameaçaram de fato o Estado britânico. Para além disso, essas rebeliões envolveram apenas uma parcela pequena dos escoceses e não visavam obter a independência escocesa, senão restaurar os Stuarts ao trono dos Três Reinos. Outro aspecto é que a República da Irlanda existe hoje em dia como um Estado soberano, o que não ocorre com a Escócia. Qualquer explicação para esse fato deve levar três pontos em con- 
sideração: 1) enquanto a Reforma protestante fracassou na Irlanda, foi bem-sucedida na Escócia; 2) na Irlanda, gaélicos, antigos ingleses (Old English) e novos ingleses (New English) se misturaram, ao passo que a divisão geográfica na Escócia entre os gaélicos (os falantes de irlandês) escoceses e os escoceses civilizados era muito mais marcada, permitindo o isolamento da Escócia gaélica e deixando a Escócia falante de inglês existir e funcionar como se, em muitos sentidos, não houvesse Escócia gaélica; 3) na Escócia, uma vez destruída a cultura gaélica, estereótipos e representações de seu imaginário puderam ser apropriados (o caso do kilt é um dos mais notáveis) ${ }^{11}$, o que não ocorreu na Irlanda. O gaélico selvagem não se tornou - exceto na literatura irlandesa nacionalista, antibritânica - no bom selvagem, em contraste, por exemplo, com a versão romantizada dos habitantes das Terras Altas escocesas, que permitiu / permite aos descendentes da Casa de Hanover usarem kilts e "tornarem-se" escoceses (mas nunca gaélicos), paralela aos desenhos satíricos dos irlandeses como macacos, comuns na literatura inglesa dos séculos XIX e XX.

Em suma, o período em pauta (1590-1691) foi vital para a formação do Estado na Grã-Bretanha e na Irlanda. Envolveu vários processos, nem sempre bem-sucedidos e por vezes contraditórios entre si, incluindo o reforço do poder do governo em face dos nobres e das fontes de poder locais, como as cidades e vilas forais. Em muitos sentidos, esse aumento no poder do Estado acabou por ter um efeito contrário na medida em que detonou crises e guerras que implicaram enormes dispêndios financeiros, restringiram a liberdade de agir do monarca e impuseram acordos com outras fontes de poder. Por outro lado, em especial no início do período, o poder do Estado foi em boa medida privatizado. Muitos postos, até mesmo militares, eram comprados e vendidos - seus detentores possuíam razoável garantia de permanência no cargo, mesmo contra o monarca -, e seus ocupantes estavam freqüentemente voltados para ações - para as quais também eram mais capacitados - que visavam a seus próprios interesses. Outro processo significativo foi a reestruturação de identidades nacionais. Ao passo que na Irlanda uma nova identidade nacional se formou para incorporar tanto os irlandeses gaélicos (Gaelic Irish) quanto os antigos ingleses (Old English), vinculados por seu catolicismo, na Inglaterra também se criava uma identidade baseada em religião, embora esta fosse mais empregada para negar Englishness, em especial aos antigos ingleses (Old English) ${ }^{12}$, vistos como tendo degenerado em irlandeses. Havia um aspecto ideológico ligado à questão religiosa. Inspirados no calvinismo, vários ingleses 
acabaram por encarar os irlandeses gaélicos (Gaelic Irish) (e, na seqüência, todos os católicos irlandeses) como algo menos do que humano, para o que as regras da guerra civilizada não se aplicavam, assim legitimando métodos terríveis, como ocorreu na Guerra dos Nove Anos e nas guerras de Cromwell. Isso provavelmente contribuiu para a ideologia "colonial" - que ignorava a existência histórica anterior da Irlanda como um reino sob a coroa britânica e cujos cidadãos tinham, portanto, direito à proteção da lei - encarar o país como "terra a ser varada a espada", um lugar a conquistar, pilhar, explorar, sem qualquer consideração pelas tradições e pelos direitos das elites leais. Apesar do sucesso da nova "conquista" da Irlanda e da retirada de cena de suas elites católicas, a incorporação da Irlanda à Grã-Bretanha representou um desafio político e ideológico; desafio que, a longo prazo, ficou sem resposta (ver Bradshaw e Morrill, 1996).

\section{CONCLUSÃO}

Dada a importância do Estado e das várias estruturas estatais no mundo contemporâneo, a análise da formação de Estados modernos pode abrir perspectivas relevantes para as ciências sociais. Apesar de vários trabalhos historiográficos e sociológicos já terem lidado com o tema, há ainda bastante espaço e necessidade de mais análises. Este artigo é uma tentativa nesse sentido. Acredito que a discussão traçada representa dois tipos de contribuição distintos. O primeiro é de ordem teórica. Apesar de fortemente inspirado no trabalho de Charles Tilly (1990) e em sua hábil correlação entre história e sociologia, em contraste com o modo como Tilly e a maioria dos outros autores que trabalham na perspectiva da sociologia histórica, não me detive num período longo de tempo, de vários séculos, antes me centrei no que considero ser o período-chave da história moderna dos dois países. Além disso, ao lidar com um dos Estados centrais na história européia moderna e um mais periférico, contribuições teóricas adicionais deverão advir da avaliação dos impactos de um sobre o outro e do desnudamento da interação complexa entre ambos. Por fim, o foco no processo e numa quantidade grande de variáveis, em vez de num único elemento explicativo chave (seja guerra, comércio ou religião), também pode ajudar na elaboração de um mapeamento mais refinado de um processo em si extremamente complexo e nuançado.

A segunda contribuição é historiográfica. Muito embora se esteja tratando da história da Grã-Bretanha e da Irlanda, nem por isso se deixa 
de lidar com a história mundial. Em certo sentido, parte da história do mundo moderno foi decidida no começo de 1602. A vitória inglesa na Guerra dos Nove Anos teve como resultante o controle total da Irlanda e abortou rotas alternativas de desenvolvimento. Isso permitiu e encorajou, entre as elites inglesas, uma orientação em direção ao Ocidente, em direção ao império e afastada do continente europeu, início do processo que redundaria no Império Britânico. Se as forças gaélicas não tivessem sido derrotadas em Kinsale, é mais do que provável que o futuro Império Britânico e o caminho que o Estado inglês tomou tivessem sido diferentes, com conseqüências significativas para o resto do mundo. Assim, ao mesmo tempo em que analisará o processo de construção do Estado em dois países europeus, a pesquisa também lidará com um dos momentos-chave da história mundial.

(Recebido para publicação em maio de 2007)

(Versão definitiva em janeiro de 2008) 
Guerra, Formação do Estado e Identidade Nacional nas Franjas...

\section{NOTAS}

1. Em inglês, o termo adequado é Britain, já que a expressão Great Britain, Grã-Bretanha, só se tornou de uso corrente no século XVIII, após a união entre Inglaterra e Escócia. Em português, o termo Bretanha tanto traduz Britain quanto Brittany, de modo que se optou por, apesar da imprecisão, empregar sempre Grã-Bretanha.

2. Em 2005, em H-Albion, uma lista importante de discussão acadêmica sobre história britânica e irlandesa, a afirmação de que a última invasão da Inglaterra fora a de Guilherme, o Conquistador não levantou qualquer celeuma. Talvez cumpra dizer que esse "fato" histórico significativo, cuja data marcaria a fundação da Inglaterra moderna - e sua separação de fato do "continente" -, é contradito por uma série de intervenções militares: várias intervenções vindas do continente ocorreram durante o período medieval, culminando com a invasão da Inglaterra por Henrique Tudor em 1485, invasões subseqüentes de iorquistas (Yorkists) oriundas da Irlanda, a invasão da Inglaterra por Guilherme de Orange em 1689 - provavelmente a última invasão bem-sucedida do país - e a invasão jacobita de 1745-1746.

3. Na maioria dos relatos sobre o período elizabetano (à exceção de um ou outro, como o de Wallace MacCaffrey,1992), ou a guerra na Irlanda é essencialmente ignorada, afora algumas menções esparsas e notas de rodapé, ou analisada em capítulo específico por um autor irlandês. Há de reconhecer que na era "pós-Pocock" houve esforços na historiografia acadêmica de endereçar as zonas não-inglesas (no sentido contemporâneo) do Estado inglês/britânico. Isso todavia não impediu que a historiografia popular sobre a era elizabetana continuasse a ignorar convenientemente a Irlanda.

4. Steven Ellis (1995) defende que algumas partes da Inglaterra, em especial as regiões das terras altas fronteiriças ao norte, eram muito semelhantes aos domínios gaélicos (e a alguns antigos ingleses (Old English)) da Irlanda, no sentido em que estavam à parte do núcleo político e socioeconômico. Segundo o autor, as condições sociais eram análogas (incursões de assalto contínuas em pequena escala, presença do mesmo nome de família em grupos extensos, punições aplicadas à coletividade etc.) e os lordes detinham uma semi-autonomia. Todavia, não obstante quão radicais e duras tenham sido as tentativas de impor disciplina a essas zonas - que incluíram o transplante de parte de sua população para a Irlanda -, jamais chegaram a ser tão severas como as que foram implementadas na Irlanda em decorrência da Guerra dos Nove Anos e da Guerra Confederada, algumas das quais podem ser classificadas como de genocídio.

5. É muito interessante observar - após tantas centenas de anos de contato, que remonta até a antes da existência da própria língua inglesa - que não há, na língua inglesa, nenhum substantivo para designar os irlandeses gaélicos (Gaelic Irish), afora o termo Gaels do século XIX, que tem um pouco outra acepção. Também vale notar que a palavra em irlandês para inglês é Sasanagh, que, literalmente, significa saxão.

6. Elizabeth - "Gloriana" e "boa rainha Bess" (Good Queen Bess) - ainda é tida em alta estima na Inglaterra. Em 2002, a BBC promoveu um concurso para indicar os melhores britânicos de sempre e ela apareceu entre os dez mais cotados. Vide BBC Press Office (2002).

7. Para além de Spenser (1997), vide, por exemplo, S.A. (1995) e Davis (1612). 


\section{Eoin $\mathbf{O}^{\prime}$ Neill}

8. Esse tipo de atitude e ação ia em progressão até os níveis hierárquicos mais elevados. Por exemplo, como Kerney Walsh (1986:31-32) descreve, na primeira década do século XVII, vários membros do Privy Council (o equivalente ao que seria o gabinete de governo) recebiam "pensões" dos espanhóis.

9. Vide, por exemplo, Brewer e Bullen (1869:87).

10. Um exemplo disso pode ser visto no incidente do Curragh, no começo de 1914, quando sessenta oficiais britânicos de serviço na Irlanda preferiram renunciar a seus postos no Exército a ter de ser responsáveis pela obediência à Home Rule (a restauração do Parlamento em Dublin), que fora promulgada pelo Parlamento de Westminster e que devia entrar em vigor no final de 1914. Esses pedidos de demissão não foram aceitos e nenhum oficial foi punido na única intervenção flagrantemente política do Exército britânico na nossa era. A entrada em vigor da Home Rule foi adiada pela erupção da Primeira Guerra Mundial.

11. Vide Trevor-Roper (1983).

12. E também, ironicamente, mais tarde, aos descendentes dos novos ingleses (New English) que se tornaram "anglo-irlandeses" (Anglo-Irish) e, mais recentemente, britânicos (British), mas nunca ingleses (English).

\section{REFERÊNCIAS BIBLIOGRÁFICAS}

BBC PRESS OFFICE. (2002), "BBC TWO Reveals the Ten Greatest Britons of All Time". Press Release, 19 de outubro. Disponível em http://www.bbc.co.uk/pressoffice/pressreleases/stories/2002/10_october/19/great_britons.shtml, acessado em 8 de maio de 2007.

BRADSHAW, Brendan e MORRILL, John (eds.). (1996), The British Problem, c. 1534-1707. London, Macmillan.

BREWER, J. S. e BULLEN, William (eds.). (1869), “A Note of Sundry Causes and Article Wherewith the Earl of Tyrone is Grieved". Calendar of the Carew Manuscripts Preserved in the Archiepiscopal Library at Lambeth 1589-1600. London, Longman \& Co.

CABALL, Marc. (1998), “Faith, Culture and Sovereignty: Irish Nationality and its Development, 1558-1625", in B. Bradshaw e P. Roberts (eds.), British Consciousness and Identity: The Making of Britain, 1533-1707. Cambridge, Cambridge University Press.

CANNY, Nicholas. (1988), Kingdom and Colony: Ireland in the Atlantic World, 1560-1800. Baltimore, John Hopkins University Press.

DAVIES, Sir John. (1612), “A Discovery of the True Causes Why Ireland Was Never Entirely Subdued nor Brought under Obedience of the Crown of England until the Beginning of His Majesty's Happy Reign", in H. Morley (ed.), Ireland Under Elizabeth and James I. London, George Routledge and Sons. 
EDWARDS, David. (2004), "Legacy of Defeat: The Reduction of Gaelic Ireland after Kinsale", in H. Morgan (ed.), The Battle of Kinsale. Wicklow, Wordwell.

ELLIS, Steven G. (1995), Tudor Frontiers and Noble Power: The Making of the British State. Oxford, Oxford University Press.

ELLIS, Steven G. (ed.). (2002), “The Empire Strikes Back: The Historiographies of Britain and Ireland", in Empires and States in European Perspective. Pisa, Edizioni Plus - Università di Pisa, Clioh's Workshop II, vol. VI.

KERNEY WALSH, Micheline. (1986), "Destruction By Peace": Hugh O'Neill after Kinsale, Glanconcadhain 1602 - Rome 1616. Armagh, Cumann Seanchais Ard Mhaca.

MACCAFFREY, Wallace T. (1992), Elizabeth I: War and Politics, 1588-1603. Princeton, Princeton University Press.

O’NEILL, Eoin. (2005), O Estado Que Nunca Foi: Guerra e Formação do Estado na Irlanda do Século XVI. Tese de doutorado em Sociologia, Iuperj, Rio de Janeiro.

PAWLISCH, Hans. (1985), Sir John Davies and the Conquest of Ireland. Cambridge, Cambridge University Press.

S.A. (1995), "The Supplication of the Blood of the English Most Lamentably Murdred in Ireland, Cryeing out of the Yearth for Revenge", in W. Maley (ed.), Analecta Hibernica, no 36. Dublin, Coimisiún Láimhscríbhinní Na hÉireann/Irish Manuscripts Commission.

SPENSER, Edmund. (1997) [1597, 1633], A View of the State of Ireland. Oxford, Blackwell.

TILLY, Charles. (1990), Coercion, Capital, and European States, AD 990-1990. Oxford, Basil Blackwell.

TREVOR-ROPER, Hugh. (1983), “The Invention of Tradition: The Highland Tradition of Scotland", in E. Hobsbawm e T. Ranger (eds.), The Invention of Tradition. Cambridge, Cambridge University Press. 


\title{
Eoin $\mathbf{O}^{\prime}$ Neill
}

\author{
ABSTRACT \\ War, State Formation, and National Identity on the Fringes of the Atlantic \\ World
}

This paper deals with the impact of war on state formation in Ireland and England, focusing on the period from 1590 to 1691, the key turning point for the future development of the state in both countries. War played a vital role, but in a number of different ways, including in the ideological sphere, in a complex process, rather than simply causing a long-term expansion in army size and subsequent growth of the state. The author further emphasizes the dynamic nature of the state itself.

Key words: state formation; Ireland; England; war; Nine Years War

\section{RÉSUMÉ}

Guerre, Formation de l'État et Identité Nationale dans lês Franges du Monde Atlantique

Dans cet article, on étudie l'impact de la guerre sur la formation de l'État en Irlande et en Angleterre, surtout dans la période de 1590 à 1691, période-clé pour le développement de l'État dans ces deux pays. La guerre y a joué un rôle très important sous plusieurs formes, et en particulier dans la sphère idéologique, au long d'un processus très complexe, au-delà de son rôle d'expansion et d'augmentation des armées et de sa conséquence, la croissance de l'État, dont il faut souligner la nature dynamique.

Mots-clé: formation de l'État; Irlande; Angleterre; guerre; Guerre de Neuf Ans 